\title{
Technological Collaboration: Bridging the Innovation Gap between Small and Large Firms*
}

\author{
by María Jesús Nieto and Lluís Santamaria
}

This paper analyzes how technological collaboration acts as an input to the innovation process and allows small and medium-sized enterprises to bridge the innovation gap with their bigger counterparts. Based on a large longitudinal sample of Spanish manufacturing firms, the results show that though technological collaboration is a useful mechanism for firms of all sizes to improve innovativeness, it is a critical factor for the smallest firms. The impact of this collaboration varies depending on innovation output and type of partner. Specifically, the impact of collaboration in small and medium-sized firms is more significant for product than process innovations. Regarding type of partner, vertical collaboration-with suppliers and clients-has the greatest impact on firm innovativeness, though this effect is clearer for medium-sized enterprises than for the smallest firms.

\section{Introduction}

Most current economies are largely composed of small and medium- sized enterprises (SMEs). In the European Union, for instance, SMEs make up 99 percent of industry and account for more than 70 percent of

\footnotetext{
*The authors thank the editor, Professor Massimo Colombo, and the two anonymous reviewers for their helpful comments and suggestions. This study has been financially supported by projects SECJ2007-67582-C02-02/ECON and CCG08-UC3M/HUM-4152. The usual disclaimer applies.

María Jesús Nieto is an Associate Professor at the Management and Strategic Division, University Carlos III of Madrid, Spain. Her current research interests include innovation management, strategic alliances, and internationalization strategy, specially focused on SMEs. She has also made recent contributions on information technology.

Lluis Santamaria is an Assistant Professor at the Department of Business Administration, University Carlos III of Madrid, Spain. His current research interests include innovation management, technological cooperation, and comparative institutional analysis. He also studies the management of intangibles and accounting information systems.

Address correspondence to: María Jesús Nieto, Universidad Carlos III de Madrid, C/Madrid, 126. 28903-Getafe, Spain. Tel: +34-91-6245826; Fax: +34-91-6245707. E-mail: mnieto@ emp.uc3m.es.
} 
employment. ${ }^{1}$ Their innovative capability is a crucial driver of sustainable competitive advantage in today's rapidly changing markets, where the continuous development of new products and processes is the key to survival, growth, and profitability (Wolff and Pett 2006; Verhees and Meulenberg 2004; Forrest 1990). This situation has fuelled growing concern among managers and policymakers and has led to a strong commitment to use policy initiatives to support innovation within SMEs (Jones and Tilley 2003; Bougrain and Haudeville 2002; Hoffman et al. 1998).

This interest is also apparent in academic circles. In the economics of innovation and technological change literature, the relationship between firm size and innovation activity has received a good deal of attention (for an overview see Cohen 1995). The Schumpeterian debate over which firms-large or small-are more able and more likely to innovate is one of the oldest in political economics, and it continues to arouse controversy today (Tsai and Wang 2005). The contradictory nature of both the conceptual and empirical findings, however, does not provide clear guidance on what to expect in general (Stock, Greis, and Fischer 2002, p. 541). Although it has not been possible to establish a strong relationship between firm size and innovation per se, some empirical research suggests that small and large firms have different determinants of innovation efforts (Rogers 2004; Van Dijk et al. 1997) and do not pursue the same types of innovation (Fritsch and Meschede 2001; Cohen and Klepper 1996; Nooteboom 1994).

These differences in innovation efforts and results can be explained by the advantages traditionally ascribed to large and small firms. The main relative strengths of SMEs lie in behavioral advantages, whereas those of large firms reside in their resource advantages (Rothwell and Dodgson 1994). Smaller firms generally enjoy internal conditions that encourage innovativeness, such as entrepreneurship, flexibility, and rapid response (Lewin and Massini 2003; Schumpeter 1942). On the other hand, the relative weaknesses of small firms compared to large ones lie in the constraints they face on gaining access to critical resources and capabilities for innovation (HewittDundas 2006). The advantages of scale and scope provided by the size of large firms make them better equipped for innovations that require large and specialized teams or sophisticated equipment (Cohen and Klepper 1992). SMEs are also usually at a disadvantage when it comes to intangible resources, as they have access to a smaller range of knowledge and human capital skills than large firms (Rogers 2004).

SMEs, however, have alternatives to internal development that may enable them to bridge the resource gap that exists with large firms (Miles, Preece, and Baetz 1999). In this respect, the literature on innovation stresses the role of cooperative $R \& D$ in overcoming the lack of internal resources and in improving innovativeness and competitiveness, particularly for SMEs (HewittDundas 2006; Rogers 2004; Bougrain and Haudeville 2002; Nooteboom 1994; among others). Indeed, SMEs engaged in technological innovation have used cooperative $R \& D$ for information exchange, resource acquisition, technology transfer, and risk management.

\footnotetext{
'Based on data from the "Informe 2003/7 del Observatorio de la PYME Europea" prepared by "Dirección General de la Pyme" (the Spanish government's Board of SMEs). Firms with fewer than 200 employees are classified as SMEs.
} 
The collaborations, though, are not homogeneous and their impact is not uniformly positive. As Freel (2003, p. 766) points out, the impact of technological collaborations varies among sectors and the type of innovation pursued.

Consequently, we need to delve more deeply into the specific role that innovation networking plays as a possible determining factor in developing the innovation capacity of SMEs (Edwards, Delbridge, and Munday 2005). This study, then, sets out to discover if collaboration, specifically technological collaboration, enables SMEs to overcome their lack of resources and capabilities, and how this in turn boosts their innovativeness. The paper analyzes the potential effect of collaboration on innovation outcomes, in terms of process and product, and goes on to reveal if innovation networking can close the gap between SMEs and large firms. The study also measures the different impact of collaborating with clients and/or suppliers (vertical collaboration) versus collaborating with research organizations such as universities or technology institutes. We believe this paper makes a novel contribution to the literature on innovation as not enough empirical research has been done on the impact of cooperative R\&D on performance, especially for SMEs (Okamuro 2007).

The paper is organized as follows. The next section develops our hypotheses based on the existing literature on technological collaboration, innovation, and firm size. The section on methodology describes the data, measures and model specification. The results are then analyzed, and the final section contains a discussion of these findings and our conclusions.

\section{Theoretical Framework Improving Innovation Capabilities through Technological Collaboration}

In technological activities, alliances, and networks are the main sources of innovation (Von Hippel 1988). An interfirm alliance can be defined as a close and deliberate collaborative relationship between independent firms and/or institutions to perform business activities. In this context, the terms "collaborative arrangements," "cooperative agreements," "strategic alliances," or "coalitions" are found throughout the literature and are often used interchangeably (Forrest 1990). These concepts do not refer to agreements involving full ownership forms, but to different configurations based on long or short-term arrangements. In the specific case of technological collaboration, these alliances include collaborative $R \& D$ agreements, university and/or research institute agreements and technology licensing.

According to Duysters, Kok, and Vaandrager (1999), alliances are no longer regarded as peripheral, but as a cornerstone of the firm's technological strategy. Indeed, over the last two decades the use of external networks by firms of all sizes has increased tremendously (Hagedoorn 2002, 1996). A growing number of studies suggest that external networks specifically create unique benefits and challenges for smaller firms (Zahra, Ireland, and Hitt 2000; Powell, Koput, and Smith-Doerr 1996). In fact, alliance formation is arguably one of the most utilized strategies for resource acquisition and leveraging by small to medium-sized enterprises (Baum, Calabrese, and Silverman 2000; Miles, Preece, and Baetz 1999). Most recently, Hewitt-Dundas (2006) finds that although a lack of partners for innovation has a negative impact on the ability of small firms to 
undertake innovation, it does not have a significant effect on the probability of innovating in larger firms. Her resourcebased interpretation of this finding is that the external resources and capabilities that small firms can access through external innovation partnerships may provide them with the stimulus and capability to innovate that they would not otherwise have.

Rogers (2004) points out that SMEs may rely more heavily on external knowledge networks as an input to innovation than do large firms. Networks allow SMEs to receive and decode flows of information. They reinforce SMEs' competitiveness by enabling them to access new knowledge, sources of technical assistance, expertise, sophisticated technology, and market requirements; they also strategically reduce the irreversibility costs of the innovation process (Freel 2005; Bougrain and Haudeville 2002).

Given that small firms seem to have potentially more to gain from innovative partnerships than larger firms, the very success of SMEs vis-à-vis their larger competitors may be due to their ability to use external networks more efficiently (Nooteboom 1994; Rothwell and Dodgson 1994). SMEs, then, have to use alliances astutely to overcome barriers to growth imposed by absolute limits to resources (Van Dijk et al. 1997; Ahern 1993). In this sense, strategic alliance formation is regarded as one of the most critical strategic actions that SMEs must undertake for survival and success (Dickson, Weaver, and Hoy 2006).

Based on the preceding discussion, we conclude that technological collaboration may be a good way of strengthening and complementing the resource endowments and capabilities of SMEs and of improving their innovativeness. Our first two hypotheses make this explicit:
H1: Technological collaboration improves innovation performance in SMEs.

H2: Technological collaboration bas a greater impact on innovation performance in SMEs than in large firms.

\section{Differences Depending on Innovation Outcomes}

Small and large firms do tend to emphasize different innovation activities (Cohen and Klepper 1996). Indeed, small and large firms are probably good at different types of innovation in accordance with their relative strengths and weaknesses (Nooteboom 1994). Large firms are likely to be better at innovations that make use of economies of scale and scope, or require large teams of specialists, such as fundamental, science-based innovations, and largescale applications (Cohen and Klepper 1992). Small firms are relatively strong in innovations where effects of scale are not important and where they can make use of their flexibility and proximity to market demand, such as new products or improvements in existing ones for niche markets, and small-scale applications (Vossen 1998; Nooteboom 1994). Cohen and Klepper (1996) show that large firms have a greater incentive to pursue all types of innovation because they can apply their innovations to a larger level of output. The same authors state that this incentive is relatively greater for innovations that depend on existing output for their exploitation, as is the case with process innovations.

Product innovations, for their part, are better instruments for entering markets than process innovations. Their characteristics enable them to answer client needs more quickly and capture new markets before competitors. In contrast, process innovations possess advantages that usually lead to productivity gains and cost reductions that indirectly affect market position. In line with this, Wolff 
and Pett (2006) find that product improvement orientation is positively associated with growth and profitability in SMEs, whereas no relationship is found with process improvement orientation.

All this may explain why SMEs tend to concentrate their efforts more on product than process innovations. The impact of size on innovation is always greater for process innovations because large firms have more facilities (internal resources and capabilities) and incentives for this type of innovation than SMEs do (Martinez-Ros 2000). Fritsch and Meschede (2001) make this point by analyzing the resources devoted to product and process R\&D. They find that small enterprises on average spend a much higher proportion of their $R \& D$ budget on new products than on new processes. Thus, if small firms focus less on process innovations, they will also produce a lower "absorptive capacity" for this type of innovations.

Bearing in mind that the impact of collaboration is not homogeneous (Freel 2003) and that SMEs and their large counterparts follow different innovation processes, the impact of technological collaboration should vary according to firm size and the innovation outcome pursued. As already seen, previous research reveals that SMEs invest less effort in and develop lower "absorptive capacity" for process innovations. In addition, as Ornaghi (2006) affirms, product improvements have a larger technological diffusion and may be simpler to learn than process innovations, which are often linked to the skills of managers or technicians. We, therefore, postulate the following hypothesis:
H3: The impact of technological collaboration varies depending on the innovation pursued. Specifically, for SMEs this impact is greater for product than for process innovations.

\section{Differences Depending on Type of Partner}

If collaboration agreements are good instruments for developing and sustaining technological capability, it follows that the choice of technological partner is crucial (Nieto and Santamaria 2007). In fact, significant differences exist among types of partners and these can determine how the collaboration is managed and what kind of innovation can be achieved (Whitley 2002). In particular, there are significant contrasts in how firms cooperate with agencies in the public science system and with suppliers and clients (vertical collaboration). ${ }^{2}$ Analyzing the relationship between type of partner and expected benefits for SME innovativeness, then, would be interesting.

Vertical collaboration with clients and/or suppliers allows a firm to gain considerable knowledge about new technologies, markets, and users' needs (Whitley 2002). Therefore, this collaboration has a significant impact on both product and process innovation and is particularly important for firms that tend to focus on a smaller set of businesses (Miotti and Sachwald 2003). As this kind of focus is typical in small firms, SMEs commonly use their suppliers and clients as a valuable source of technological information. Many innovations by small firms, then, are based on off-the-shelf technologies, concepts, and/or resources offered by supplying industries (Verhees and Meulenberg 2004). Consequently,

\footnotetext{
${ }^{2}$ Most of the theoretical literature also analyzes cooperative agreements between competitors. As occurs in other studies (Cassiman and Veugelers 2002), however, the number of firms in our sample that collaborate with competitors is very low. For this reason we do not include this type of agreement.
} 
suppliers may play a more active role in stimulating innovation by trying to influence the small firm's innovation decision. Meanwhile, the relationship between innovativeness and market intelligence makes client information a key resource for innovation in small firms (Verhees and Meulenberg 2004).

Research organizations (that is universities and technology institutes) have not traditionally focused on filling out the innovation processes of firms, but on providing them with new scientific and technological knowledge (Drejer and Jørgensen 2006). This has changed in the last few years, however, and these organizations have been under considerable pressure to move closer to industry. Two main reasons exist for this change. First, governments have encouraged them to undertake more research directed at boosting the competitiveness of industry (Tether 2002). Second, pressure on funding has pushed universities into greater collaboration with industry (Gibbons et al. 1994). In fact, several studies document the important role that universities and other research institutions have on technological innovation (Vuola and Hameri 2006; Bozeman 2000).

Although large firms are more likely to collaborate with universities and research centers (Bayona, Garcia-Marco, and Huerta 2002), several empirical studies indicate that SME innovations receive significant spillovers from university research (Piergiovanni, Santarelli, and Vivarelli 1997; Acs, Audretsch, and Feldman 1994). Public research institutes-apart from conducting their own studies-can provide small local firms with solutions to technical problems in product development. Indeed, the previous studies show that public research institutes play a key role in localized knowledge spillovers received by small firms (Izushi 2003; Beise and Stahl 1999).
And yet formidable barriers may prevent SMEs from exploiting research organizations. These barriers exist because SMEs are often unaware of their real requirements or have problems expressing them (Lambrecht and Pirnay 2005). Firms may not know what types of services they need to develop innovations (Izushi 2003) or which technological partners have the most relevant capabilities (Geisler 1997). For these reasons fluid and clear communication between technological partners and firms is important, particularly when the firms are SMEs (Smallbone, North, and Leigh 1993). Another barrier, however, may exist because research organizations are not overstocked with experts with the specific "technoeconomic" capabilities to support SME innovation processes and resolve the communication problems that can arise (Rolfo and Calabrese 2003).

These arguments seem to suggest that different types of collaboration (vertical partners versus research organizations) will have different impacts on the innovativeness of SMEs. Collaboration with research organizations (despite their increasing focus on industrial needs) may be problematical for SMEs, whereas partnerships with clients and suppliersbecause of their characteristics-seem likely to have the greatest impact on SME innovation processes. Our last hypothesis, then, posits:

H4: The impact of technological collaboration varies according to the partner chosen. Specifically, for SMEs the impact of vertical partnerships is greater than the impact of collaboration with research organizations.

\section{Methodology}

Sample and Data

The source for our empirical analysis is the Spanish Business Strategies Survey (SBSS). This is an annual firm-level panel of data compiled by the Spanish Ministry 
of Industry and the Public Enterprise Foundation; it has been used by many other researchers to study innovation (Cuervo-Cazurra and Un 2007; Beneito 2006; Huergo 2006, among others). The SBSS contains an interesting and wide set of variables on Spanish firms operating in all manufacturing industries of the classification NACE-Rev.1.

The sample is representative of the population of Spanish manufacturing firms. Firms with between 10 and 200 employees are selected through a random stratified sample (according to firm size and industry classification), and firms with more than 200 employees are surveyed on a census base (Huergo 2006). The empirical analysis is based on the balanced sample of firms with information available for the complete period from 1998 to 2002. Our final sample contains 6,500 observations from 1,300 firms that have remained in the survey during the whole five-year period.

\section{Measures}

Dependent Variables: Innovation Outputs. The dependent variables are relative to firm innovation performance in a specific period $t$. In order to capture the different innovation outputs, three separate measures were used: innovation, product innovation, and process innovation. Innovation is a dichotomous variable that takes value 1 when the firm declares at least one product innovation and/or at least one process innovation in the survey year; otherwise its value is 0 . Product Innovation is a dichotomous variable that takes value 1 when the firm declares it has introduced completely new products or products with important modifications, products with new func- tions resulting from innovation, or has made changes to the design, presentation, materials, or composition of the product. Otherwise its value is 0 . Lastly, Process Innovation is assumed to have happened when the firm indicates it has introduced some significant modification in the production process. This modification may involve the introduction of new machines or new methods of organization, or the introduction of both. It is also a dichotomous variable.

Independent Variables. Given the objectives of the research, the study attempts to measure the potential innovative behavior of SMEs, especially how this behavior is affected by technological collaboration. To take account of technological collaboration, a dichotomous variable (Collaboration) that indicates whether firms have collaborated technologically with other firms or research organizations was constructed. This technological collaboration includes different modes of technology partnering that Hagedoorn (1993) defines as contractual arrangements: joint $R \& D$ agreements, technology exchange agreements, and other technology flows such as licensing. Collaboration takes value 1 when the firm is involved in at least one of these contractual arrangements; the variable is lagged one period in the models. ${ }^{3}$

In order to gauge the impact of collaboration depending on firm size, firms were sorted using three dichotomous variables: (1) Small takes value 1 when the firm has fewer than 50 employees; (2) Medium takes value 1 when the firm has between 50 and 200 employees; and (3) Large takes value 1 when the firm has more than 200 employees. This makes it possible to measure the effect of collabo-

\footnotetext{
'The models in this study include independent variables lagged one period. Other estimations with variables lagged two periods were also performed and highly robust results were obtained. In order to retain the largest number of years and observations possible, the one-period option was selected.
} 
ration in each size category with the following crossed effects (also included as lagged variables):

$$
\begin{gathered}
\text { Collaboration }=\text { Small } \times \text { Collaboration } \\
+ \text { Medium } \times \text { Collaboration } \\
+ \text { Large } \times \text { Collaboration }
\end{gathered}
$$

To test the final hypothesis, firms that have collaborated technologically with clients and/or suppliers (Vertical) and others that have done the same with universities and/or technology institutes (Research Organizations) were identified. These dichotomous variables were also included in the models as lagged variables and were subdivided in each size category. Thus:

$$
\begin{gathered}
\text { Vertical }=\text { Small } \times \text { Vertical }+ \text { Medium } \\
\times \text { Vertical }+ \text { Large } \times \text { Vertical } \\
\text { Resarch Organizations }=\text { Small } \times R O \\
+ \text { Medium } \times R O+\text { Large } \times R O
\end{gathered}
$$

To enable us to compare the impact of technological collaboration depending on the size of the firm, each model included-together with the interaction terms-the three previously defined categories of firm size: Small, Medium, and Large.

Control Variables. To accurately measure the effect that technological collaboration has on innovativeness, other potential inputs to firms' innovation processes need to be considered: in particular, formal R\&D activities (internal and/or external), design and the use of technological consultants. To avoid problems of simultaneity with the innovation generation process, these innovation activities are lagged one period. $R \& D$ investment is now generally seen as a crucial determinant of innovation, because it helps firms create, absorb, exploit, and transform new knowledge into new products and/or processes
(Becheikh, Landry, and Amara 2006). Formal RED captures the decision to perform $R \& D$ activities (in-house and/ or contracted) and is measured as the ratio of R\&D expenditures to total sales. Design covers a wide range of activities-including architectural, fashion, interior, graphic, industrial, and engineering-that can be implemented in a variety of contexts. Design allows the firm to incorporate what customers want, what can be more efficiently produced, and what fits better with the firm's other products, strategy, and image (Walsh 1996). The dichotomous variable Design measures the performance and/or contracting of these activities. Lastly, technological consultants may represent another source of innovation. Consultants often interact with numerous firms across a variety of industries and may transfer tacit knowledge developed through this ongoing experience (Bierly and Daly 2007). The dichotomous variable Consultant identifies if a firm uses a technological consultant.

Additional controls for firm-specific characteristics and sector of activity were included. The age of the firm (Age)-calculated as the number of years since a firm's foundation-measures firm experience and learning, and is also a commonly used variable in empirical studies of innovation (Kumar and Saqib 1996). Numerous studies recognize the effect of ownership structure on innovation and track its influence by focusing on foreign ownership, although the empirical evidence is not conclusive (see Becheikh, Landry, and Amara 2006). To control for its potential impact, the percentage of foreign equity in a firm's capital was included (Foreign). Export and internationalization have a positive and significant effect on innovation (Galende and De la Fuente 2003). To remain competitive in foreign markets, firms need to innovate constantly (Veugelers and Cassiman 1999). Export 
intensity (Export), then, was also included-calculated as the ratio of the firm's sales in foreign markets to total sales.

Eighteen industry dummies were used to capture the effect of sector characteristics related to life cycles and technological regimes on innovation. The firms' activity classification is an aggregation of the two-digit manufacturing industries classification in the NACE-Rev.1 (for similar classifications see Huergo 2006).

Table 1 contains the descriptive statistics and correlations of the independent and control variables used in this study (with the exception of the sector dummies).

\section{Model Specification}

To test the first two hypotheses, two sets of models were specified with the dependent variable Innovation (with no distinction between product and process innovations). The first model (Model A1) analyzes the impact of Collaboration on innovativeness, whereas the second (Model A2) attempts to capture the subtleties of technological collaboration for each size category. Both models include the rest of the innovation activities, the firm-specific controls, and the sector dummies.

Positive and significant coefficients of the interaction terms Small $\times$ Collaboration and Medium $\times$ Collaboration are required for $\mathrm{H} 1$ to be supported. A greater and significant impact of collaboration for SMEs in comparison to large firms must be observed for $\mathrm{H} 2$ to be supported. Two wald tests were performed to test the significance of the difference of coefficient estimates.

Given the binary character of the dependent variable, probit models were specified. To address concerns of unobserved heterogeneity, a random-effects panel probit model was employed. Our decision to use a random-effects model instead of a fixed-effects model was based on the following: (1) our sample was drawn from a large population; in this setting, it might be more appropriate to view individual specific constant terms as randomly distributed across crosssectional units (Greene 2000, p. 567); (2) estimates computed using fixed-effects model can be biased for panels over short periods. This is not a problem with random-effects models (Hsiao 1986; Heckman 1981). Given that all the firmyear observations in our sample were present for only five years, randomeffects was the preferred approach; and (3) fixed-effects models cannot include time-independent covariates. Our analysis could be limited without these variables.

In order to test $\mathrm{H} 3$ and $\mathrm{H} 4$, we differentiate between product and process innovations. As these two types of innovations may be related to each other (Fritsch and Meschede 2001; MartínezRos 2000), the error terms of the two models are likely to be correlated. Thus, an extension of probit known as bivariate probit (Greene 2000) is usually a more appropriate estimator. The bivariate probit model has the following specification:

$$
\begin{aligned}
& Z_{i 1}=\beta_{1}^{\prime} x_{i 1}+\varepsilon_{i 1} ; y_{i 1}=1 \text { if } z_{i 1}>0, y_{i 1}=0 \\
& \text { if } z_{i 1} \leq 0 \\
& \begin{aligned}
& Z_{i 2}= \beta_{2}^{\prime} x_{i 2}+\varepsilon_{i 2} ; y_{i 2}=1 \text { if } z_{i 2}>0, y_{i 2}=0 \\
& \text { if } z_{i 2} \leq 0 \\
& \quad\left(\varepsilon_{i 1}, \varepsilon_{i 2}\right)-N(0,0,1,1, \rho)
\end{aligned}
\end{aligned}
$$

This model produces estimates of the coefficient vectors $\beta_{1}$ and $\beta_{2}$ for the two equations, of $\rho$ (the correlation between the error terms $\varepsilon_{i j}$ of the equations), and of the standard errors for these parameters. Our tests revealed that the correlation between the equations was statistically significant, which is an indicator that the bivariate model was more effective than the separate probit models (Greene 2000, pp. 853854). 
Table 1

Descriptive Statistics, Correlations, and Collinearity Diagnostics of the Independent and Control Variables

\begin{tabular}{|c|c|c|c|c|c|c|c|c|c|c|c|c|c|c|c|}
\hline & & Mean & S.D. & 1 & 2 & 3 & 4 & 5 & 6 & 7 & 8 & 9 & 10 & $\mathbf{V I F}^{\mathrm{a}}$ & $\mathbf{V I F}^{\mathrm{b}}$ \\
\hline 1 & Collaboration & 0.337 & 0.472 & & & & & & & & & & & 1.65 & \\
\hline 2 & Vertical & 0.258 & 0.438 & 0.83 & & & & & & & & & & & 1.62 \\
\hline 3 & RO & 0.224 & 0.417 & 0.75 & 0.49 & & & & & & & & & & 1.53 \\
\hline 4 & Small & 0.515 & 0.499 & -0.46 & -0.42 & -0.40 & & & & & & & & 2.65 & 2.75 \\
\hline 5 & Medium & 0.199 & 0.399 & 0.03 & 0.01 & -0.01 & -0.51 & & & & & & & 1.55 & 1.60 \\
\hline 6 & Formal R\&D & 0.007 & 0.023 & 0.34 & 0.33 & 0.29 & -0.18 & 0.02 & & & & & & 1.16 & 1.18 \\
\hline 7 & Design & 0.289 & 0.453 & 0.32 & 0.33 & 0.23 & -0.27 & 0.04 & 0.19 & & & & & 1.17 & 1.18 \\
\hline 8 & Consultant & 0.226 & 0.418 & 0.42 & 0.39 & 0.37 & -0.28 & -0.01 & 0.18 & 0.21 & & & & 1.21 & 1.21 \\
\hline 9 & Age & 25.20 & 20.93 & 0.21 & 0.18 & 0.18 & -0.34 & 0.06 & 0.10 & 0.16 & 0.10 & & & 1.17 & 1.17 \\
\hline 10 & Export & 0.198 & 0.264 & 0.36 & 0.33 & 0.30 & -0.45 & 0.12 & 0.17 & 0.20 & 0.18 & 0.11 & & 1.38 & 1.38 \\
\hline \multirow[t]{2}{*}{11} & Foreign & 18.72 & 37.71 & 0.28 & 0.27 & 0.21 & -0.43 & 0.07 & 0.05 & 0.10 & 0.11 & 0.19 & 0.33 & 1.33 & 1.33 \\
\hline & & & & & & & & & & & & & Mean VIF & 1.47 & 1.50 \\
\hline
\end{tabular}

S.D., standard deviation; VIF, variance inflation factor; RO, research organization.

${ }^{a}$ Models A1, A2, and B.

'Model C. 
Two bivariate probit models were estimated to test H3 (Model B) and H4 (Model C). Both models include the independent variables, the firm-specific controls, and sector and year dummies. The Wald tests comparing the difference of coefficient estimates-product innovation versus process innovation-must be significant in the SME categories to support $\mathrm{H} 3$. The set of Wald tests for H4 compare the difference of coefficients estimates-vertical versus RO (research organization) collaboration-in each size category and type of innovation. For $\mathrm{H} 4$ to be supported, a greater and significant effect of vertical partnerships must be observed for SMEs.

Our models were also analyzed for potential endogeneity and multicollinearity problems. We test for endogeneity by using an instrumental variable approach for probit regressions (Smith and Blundell 1986). The test specifies that the exogeneity of one or more of the explanatory variables is under suspicion. Our interest was to check that no endogeneity problems between collaboration variables and innovation results existed. Under the null hypothesis, the model is appropriately specified with all explanatory variables as exogenous. Under the alternative hypothesis, the suspected endogenous variables are expressed as linear projections of a set of instruments, ${ }^{\prime}$ and the residuals from those first-stage regressions are added to the model. Under the null hypothesis, these residuals should have no explanatory power. Estimation of the model gives rise to a test for the joint hypothesis that each of the coefficients on the residual series is zero. The Smith-Blundell test statistic is evaluated with respect to a $\chi^{2}$ distribution in the number of potentially endogenous variables, and the associated $p$-value either rejects or not the null hypothesis. The test was repeated for the different combinations of collaboration variables and innovation outputs for all of the models. The null hypothesis of exogeneity was not rejected in any case, ${ }^{5}$ thus indicating that the collaboration variables should be employed.

To test for multicollinearity, an analysis of the variance inflation factor (VIF) was conducted. Individual VIF values greater than 10 indicate a multicollinearity problem (Neter, Wasserman, and Kutner 1989), along with average VIF values greater than six. The values presented in Table 1 show that problems of multicollinearity do not exist in any of the models.

\section{Analysis and Results}

Table 2 displays some descriptive figures on different size firms (small, medium, and large), their innovation outcomes and their degree of technological collaboration. These results show that for the full sample (6,500 observations), small firms are much less likely to innovate than large ones, whichever the innovation outcome analyzed. Thus, a marked innovation gap between SMEs and their large counterparts exists. When the focus is limited to the subsample of collaborative firms (2,181 observations), however, this gap appreciably narrows. Moreover, the percentages of firms

\footnotetext{
'Specifically, several variables that the literature identifies as potential determinants were used to instrumentalize collaboration (Izushi 2003; Miotti and Sachwald 2003; Cassiman and Veugelers 2002, among others): search for public finance, technological forecasting activities, participation in international innovation programs, and market expansion goals. These instruments were lagged one period with respect to the collaboration.

'Smith-Blundell test statistics give different Chi-squared distributions between 0.1106 and 2.0559 . Their $p$-values were between, 35 and .84 . These test results are available from the authors on request.
} 


\section{Table 2}

\section{Technological Collaboration and Innovation Results}

\begin{tabular}{|c|c|c|c|c|c|c|c|c|}
\hline \multirow[t]{2}{*}{$\begin{array}{l}\text { Percentage } \\
\text { of Firms }\end{array}$} & \multicolumn{4}{|c|}{$\begin{array}{c}\text { Total Sample } \\
(6,500 \text { observations })\end{array}$} & \multicolumn{4}{|c|}{$\begin{array}{l}\text { Collaborative Firms } \\
(2,181 \text { Observations })\end{array}$} \\
\hline & Total & $\begin{array}{l}\text { Small } \\
\text { Firms }\end{array}$ & $\begin{array}{l}\text { Medium } \\
\text { Sized } \\
\text { Firms }\end{array}$ & $\begin{array}{l}\text { Large } \\
\text { Firms }\end{array}$ & Total & $\begin{array}{l}\text { Small } \\
\text { Firms }\end{array}$ & $\begin{array}{c}\text { Medium } \\
\text { Sized } \\
\text { Firms }\end{array}$ & $\begin{array}{l}\text { Large } \\
\text { Firms }\end{array}$ \\
\hline $\begin{array}{l}\text { Technological } \\
\text { Collaboration }\end{array}$ & 33.5 & 12.2 & 36.3 & 70.1 & & & & \\
\hline $\begin{array}{l}\text { Technological } \\
\text { Innovation }\end{array}$ & 44.6 & 32.5 & 46.6 & 65.2 & 72.2 & 69.5 & 68.3 & 74.5 \\
\hline $\begin{array}{l}\text { Product } \\
\text { Innovation }\end{array}$ & 24.6 & 14.6 & 26.9 & 41.3 & 48.2 & 47.8 & 47.2 & 48.7 \\
\hline $\begin{array}{l}\text { Process } \\
\text { Innovation }\end{array}$ & 34.9 & 24.1 & 35.1 & 54.4 & 57 & 45.4 & 50.2 & 63.2 \\
\hline
\end{tabular}

"Product and/or process innovations.

achieving product innovations are similar in all three categories of firm size.

Despite the substantial improvement in the innovation outcomes of collaborating SMEs, small firms tend to collaborate far less than large ones do. Fewer than one out of eight small firms collaborates, a figure that rises to slightly more than one out of three for medium-sized firms and almost three out of four for large firms. This tendency of SMEs to collaborate less than large firms is generalizable to a large number of European countries for the period under study (European Commission 2004).

Figure 1 illustrates these points by showing the historical trends of the product and process innovation gaps for the years in the sample (1998-2002); it clearly shows the narrowing of the innovation gap in the subsample of collaborating firms, especially for product innovations.

A series of econometric analyses were performed to test the hypotheses put forward in the theoretical section and to corroborate the picture suggested by the description of the sample. Table 3 shows the estimation results of two series of probit models (Models A1 and A2) with random effects; these results test $\mathrm{H} 1$ and $\mathrm{H} 2$ by analyzing the impact of technological collaboration on innovation outcomes (with no distinction between product and process innovation). Estimated coefficients and marginal effects from our probit models are presented for each model. Marginal effects were computed at the means of the independent variables and show how much the probability of a firm's innovating grows with an increase in that independent variable, while holding the other independent variables constant.

Model A1 reveals the positive impact of collaboration on the likelihood of firms in the sample-regardless of size-innovating. Model A2 captures the different marginal effect of collaboration depending on size category. These results confirm the relationship postulated in $\mathrm{H} 1$. Thus, technological 


\section{Figure 1 \\ Evolution of Innovation Gap and the Effect of Technological Collaboration}

Percentage of innovative firms (Product innovation)
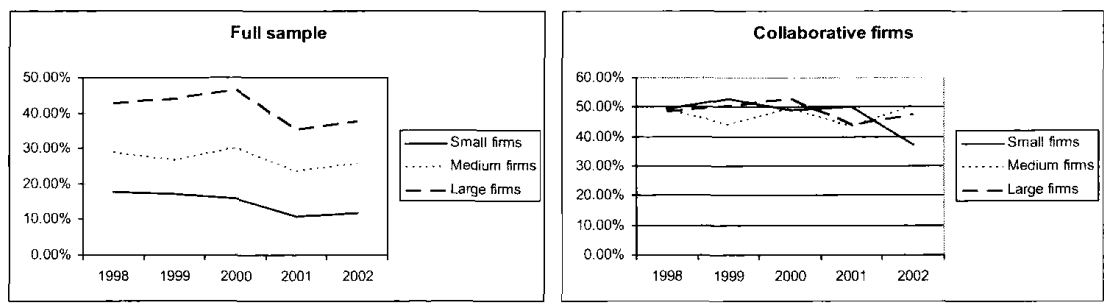

Percentage of innovative firms (Process innovation)
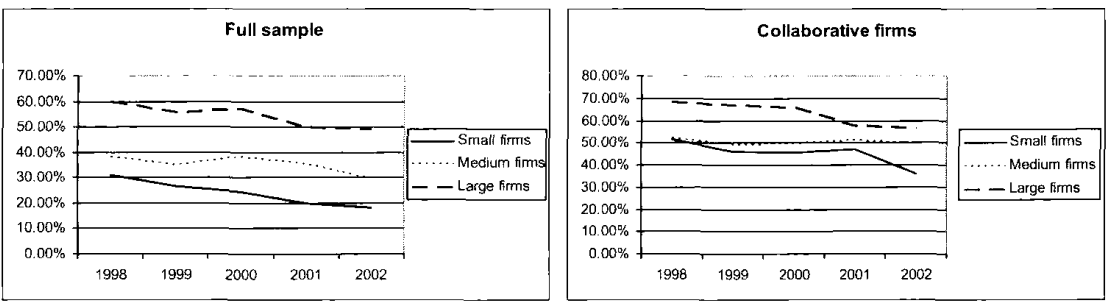

collaboration increases the likelihood that SMEs achieve innovations. The Wald tests used to test $\mathrm{H} 2$ are shown at the bottom of Table 3. H2's postulation that the impact of collaboration will be greater for the subsample of SMEs is corroborated for small firms. ${ }^{6}$ This effect, however, is not greater in medium-sized firms. Collaboration, then, may be helping the small firms to bridge the innovation gap with large firms.

As expected, the marginal effect of other innovation activities (formal $R \& D$, design or consultants) is positive and significant for innovation output. The negative and significant effect exerted by firm age suggests that older firms develop routines, procedures, and inertia that may be barriers to innovation.

Bivariate probit models were used to test $\mathrm{H} 3$ and $\mathrm{H} 4$. These specifications allow us to explore the differential effect of collaboration on two measures of innovation outputs for each category of firm size. As explained in the section on methodology, the $\rho$ parameter is highly significant, signaling that the error structures of the equations are correlated.

'The robustness of these findings was tested with additional measures related to firm size. Specifically, the introduction of alternative firm size categories and the inclusion of the cross term of sales and collaboration dummy were tested. In all cases the results were highly robust. These test results are available from the authors on request. 
Table 3

Innovation Performance, Technological Collaboration, and Firm Size

\begin{tabular}{|c|c|c|c|c|}
\hline & \multicolumn{2}{|c|}{ Model A1 } & \multicolumn{2}{|c|}{ Model A2 } \\
\hline & $\begin{array}{c}\text { Probit } \\
\text { Estimates }\end{array}$ & $\begin{array}{c}\text { Marginal } \\
\text { Effects } \\
(d y / d x)\end{array}$ & $\begin{array}{c}\text { Probit } \\
\text { Estimates }\end{array}$ & $\begin{array}{c}\text { Marginal } \\
\text { Effects } \\
(d y / d x)\end{array}$ \\
\hline Collaboration & $0.391^{* * * *}(4.31)$ & $0.137^{* * * *}(4.37)$ & & \\
\hline Small $\times$ Collaboration & & & $0.989^{* * * *}(7.09)$ & $0.375^{* * * * *}(8.23)$ \\
\hline Medium $\times$ Collaboration & & & $0.442 * * *(3.07)$ & $0.174^{\text {***** }}(3.07)$ \\
\hline Large $\times$ Collaboration & & & $0.651 * * *(5.07)$ & $0.254 * * *(5.17)$ \\
\hline Small & $0.423^{* * *}(2.76)$ & $0.145^{* * * *}(2.92)$ & $-0.888^{* * *}(-7.12)$ & $-0.332^{\text {***** }}(-7.80)$ \\
\hline Medium & $0.380^{* *}(2.11)$ & $0.126^{* *}(2.30)$ & $-0.431 * * *(-2.76)$ & $-0.157^{* \ldots *}(-2.98)$ \\
\hline Large & $0.559^{* * * *}(2.81)$ & $0.195^{* * *}(3.02)$ & $-0.212(-1.16)$ & $-0.080(-1.18)$ \\
\hline Formal R\&D & $3.623^{* * * *}(2.78)$ & $1.282^{* * *}(2.75)$ & $5.130^{* * *}(3.32)$ & $1.969^{* * *}(3.32)$ \\
\hline Design & $0.213^{* * *}(2.61)$ & $0.075^{* * * *}(2.59)$ & $0.479^{* * *}(6.31)$ & $0.186^{* * * *}(6.31)$ \\
\hline Consultant & $0.202^{* * *}(2.58)$ & $0.069^{* *}(2.45)$ & $0.333^{* * * *}(4.29)$ & $0.130 * * *(4.26)$ \\
\hline Age & $-0.005^{* *}(-2.27)$ & $-0.002^{* *}(-2.22)$ & $-0.003^{*}(-1.76)$ & $-0.001^{*}(-1.75)$ \\
\hline Foreign & $-0.002 *(-1.87)$ & $-0.001^{*}(-1.82)$ & $-0.001(-1.35)$ & $-0.001(-1.35)$ \\
\hline Export & $-0.149(-0.86)$ & $-0.053(-0.86)$ & $0.149(0.96)$ & $0.057(0.96)$ \\
\hline Wald Test of Full Model: $\chi^{2}$ & $173.34^{* * * *}$ & & $437.85^{* * * *}$ & \\
\hline Log Pseudo-Likelihood & $-1,660.13$ & & $-2,230.42$ & \\
\hline Comparison Tests & & & $\begin{array}{l}\beta^{\text {Small } \times \text { collab }}>\beta^{\text {Larg }} \\
\beta^{\text {Med } \times \text { Collab }}>\beta^{\text {Large }}\end{array}$ & $\begin{array}{l}: \chi^{2}=4.12^{* *} \\
\chi^{2}=1.22 \text { (n.s.) }\end{array}$ \\
\hline
\end{tabular}

$\mathrm{t}$-Values are in parentheses. Sectoral dummies are included in the models. Marginal effects are computed at sample means. For dummy variables, the marginal effect corresponds to the discrete change from 0 to 1 . n.s., non-significant.

${ }^{a}$ Wald test comparing the difference of coefficients estimates.

${ }^{*} p<.10$.

${ }^{* *} p<.05$.

$* * * p<.01$. 
This suggests that product and process innovation are not independent and that the bivariate model is a more appropriate specification. The estimated coefficients and marginal effects are presented in Tables 4 and 5. Marginal effects were calculated for the three scenarios: (1) when the firm achieves only product innovations, (2) when the firm achieves only process innovations, and (3) when the firm achieves both product and process innovations.

Table 4 contains the estimations to test $\mathrm{H3}{ }^{7}$ The estimated coefficients indicate that the impact of collaboration on the likelihood of innovation is positive for all size categories, both for product and process innovations. A first examination of these results reveals that collaboration-independent of firm size category-exerts a greater impact on the likelihood of achieving product innovations. The estimates and wald tests shown in Table 4 confirm that the impact of technological collaboration varies depending on the innovation pursued. Moreover, for SMEs this impact is significant and greater for product innovations, as postulated in $\mathrm{H} 3$.

Analyzing the marginal effects that separate the impacts of collaboration for each innovation output alternative is more interesting. This analysis confirms $\mathrm{H} 3$, while also making it possible to obtain a more precise picture of what is happening. In firms that only achieve product innovations, the marginal effect of collaboration is greater in SMEs. In firms that only achieve process innova- tions, however, the marginal effect of collaboration is only positive and significant in larger firms. In firms that achieve product and process innovations, once again the marginal effect of collaboration is positive for all size categories.

No substantial differences exist between the rest of variables and the initial models. The fact that age does not exert a negative and significant effect on product innovation leads us to conclude that organizational inertia is a barrier to achieving process innovations. In addition, export intensity is revealed as a positive factor for product innovation outcomes. This squares with the idea that the desire to be competitive in international markets pushes firms to improve their products more frequently.

Lastly, the model in Table 5 captures the differential effect of the various types of collaboration depending on technological partner $(\mathrm{H} 4){ }^{8}$ The estimated coefficients of each technological partner show a positive impact on the likelihood of innovating. Specifically, vertical collaboration always has a greater impact than collaboration with research organizations (for all firm size categories and innovation outcomes). Two sets of Wald tests comparing the difference of coefficient estimates (vertical versus $R O$ ) were calculated to check whether this greater impact was statistically significant. These tests reveal that $\mathrm{H} 4$ is only partially supported because the impact of vertical collaboration is significantly greater than that of collaboration with ROs for

\footnotetext{
Table 4 presents the results of the estimations for the full sample. The analyses were repeated for the subsample of innovating firms in order to control for potential sample selection problems (Piga and Vivarelli 2004), which arise from the endogenous decision not to introduce innovation (see Table Al in the Appendix). Although the impact of some variables of interest differs slightly, the interpretation of the hypotheses is similar to that obtained with the full sample.

"Table 5 presents the results of the estimations for the full sample. These analyses were also repeated for the subsamples of innovating firms (see Table A2 in the Appendix). Once again, the meaning of the hypotheses is similar to that obtained with the full sample.
} 
Product and Process Innovations, Technological Collaboration, and Firm Size

\begin{tabular}{|c|c|c|c|c|c|}
\hline & \multicolumn{5}{|c|}{ Model B } \\
\hline & \multicolumn{2}{|c|}{ Bivariate Probit Estimates } & \multicolumn{3}{|c|}{ Marginal Effects $(d y / d x)$} \\
\hline & $\begin{array}{c}\text { Product } \\
\text { Innovation }\end{array}$ & $\begin{array}{c}\text { Process } \\
\text { Innovation }\end{array}$ & $\begin{array}{l}\text { Only Product } \\
\text { Innovation }\end{array}$ & $\begin{array}{l}\text { Only Process } \\
\text { Innovation }\end{array}$ & $\begin{array}{l}\text { Both Product } \\
\text { and Process }\end{array}$ \\
\hline Small $\times$ Collaboration & $0.929 *(9.93)$ & $0.468^{* k * * *}(5.14)$ & $0.114^{* * * *}(4.90)$ & $-0.035(-1.52)$ & $0.214^{* * * * * *}(7.71)$ \\
\hline Medium $\times$ Collaboration & $0.603^{* * *}(5.92)$ & $0.346^{* *}(3.58)$ & $0.069^{* * * *}(3.12)$ & $-0.001(-0.05)$ & $0.131^{* * * *}(5.09)$ \\
\hline Large $\times$ Collaboration & $0.508^{* * * *}(5.63)$ & $0.505^{* * *}(5.87)$ & $0.032^{* *}(1.98)$ & $0.062 * *(2.49)$ & $0.127^{* * * *}(6.07)$ \\
\hline Small & $-1.485^{* \cdots \cdots k}(-17.90)$ & $-0.754^{* * *}(-10.84)$ & $-0.159^{* * * * *}(-13.03)$ & $-0.014(-0.79)$ & $-0.251^{* * *}(-19.38)$ \\
\hline Medium & $-1.201^{\text {****: }}(-13.63)$ & $-0.563 * * * 6.18)$ & $-0.108^{* * *}(-13.11)$ & $-0.050^{* *}(-2.27)$ & $-0.130^{* * *}(-17.08)$ \\
\hline Large & $-1.029^{* * *}(-8.64)$ & $-0.409^{* * * *}(-3.78)$ & $-0.108^{* * * *}(-8.64)$ & $-0.011(-0.39)$ & $-0.127^{* * * *}(-10.67)$ \\
\hline Formal R\&D & $2.314^{* * *}(2.44)$ & $1.653^{*}(1.78)$ & $0.232 *(1.71)$ & $0.170(0.66)$ & $0.417^{* * * * * *}(2.72)$ \\
\hline Design & $0.484^{*} *(9.36)$ & $0.317^{* * * * *}(6.34)$ & $0.051^{* * * *}(5.27)$ & $0.020(1.45)$ & $0.095^{* * * *}(9.07)$ \\
\hline Consultant & $0.211^{\text {*k-k*** }}(3.81)$ & $0.405^{* * *}(7.68)$ & $-0.003(-0.40)$ & $0.084^{* * * * *}(5.38)$ & $0.065^{* * * *}(5.97)$ \\
\hline Age & $-0.001(-0.55)$ & $-0.003^{* *}(-2.37)$ & $0.001(0.62)$ & $-0.001^{* *}(-2.09)$ & $-0.001 *(-1.69)$ \\
\hline Foreign & $-0.001(-1.15)$ & $-0.001 *(-1.69)$ & $-0.000(-0.31)$ & $-0.001(-1.12)$ & $-0.001 *(-1.78)$ \\
\hline Export & $0.163^{*}(1.81)$ & $0.064(0.68)$ & $0.021(1.29)$ & $-0.002(-0.10)$ & $0.024^{*}(1.71)$ \\
\hline Wald Test of Full Model: $\chi^{2}$ & \multicolumn{5}{|c|}{$2,125.02^{* * * *}$} \\
\hline Log Pseudo-Likelihood & \multicolumn{5}{|c|}{$-4,119.29$} \\
\hline $\mathrm{LR} \sim \chi^{2}: \rho=0$ & \multicolumn{5}{|c|}{$\begin{array}{l}\chi^{2}=155.43^{* * *} \\
\beta_{\text {smill } \times \text { cullab }}(\text { product })>\beta^{\text {small } \times \text { collab }}(\text { process }): \chi^{2}=16.02^{* * * *}\end{array}$} \\
\hline Comparison Tests ${ }^{\mathrm{a}}$ & \multicolumn{5}{|c|}{$\begin{array}{l}\beta^{\text {Smill } \times \text { collab }}(\text { product })>\beta^{\text {small } \times \text { collal }} \text { (process): } \chi^{2}=16.02^{* * * *} \\
\beta^{\text {Med } \times \text { collab }}(\text { product })>\beta^{\text {Med } \times \text { collah }} \text { (process): } \chi^{2}=4.28^{* * *} \\
\beta^{\text {small } \times \text { collab }}(\text { product })>\beta^{\text {large } \times \text { collab }} \text { (process): } \chi^{2}=0.01 \text { (n.s.) }\end{array}$} \\
\hline
\end{tabular}

$\mathrm{t}$-Values are in parentheses. Sectoral and yearly dummies are included in the models. Marginal effects are computed at sample means. For dummy variables, the marginal effect corresponds to the discrete change from 0 to 1 . n.s., non-significant.

"Wald test comparing the difference of coefficients estimates (product innovation versus process innovation) in each size category.

${ }^{*} p<.10$.

$* * p<.05$

$* * * * 0.01$. 
Table 5

Type of Partner, Technological Collaboration, and Firm Size

\begin{tabular}{|c|c|c|c|c|c|}
\hline & \multicolumn{5}{|c|}{ Model C } \\
\hline & \multicolumn{2}{|c|}{ Bivariate Probit Estimates } & \multicolumn{3}{|c|}{ Marginal Effects (dy/dx) } \\
\hline & $\begin{array}{c}\text { Product } \\
\text { Innovation }\end{array}$ & $\begin{array}{c}\text { Process } \\
\text { Innovation }\end{array}$ & $\begin{array}{l}\text { Only Product } \\
\text { Innovation }\end{array}$ & $\begin{array}{l}\text { Only Process } \\
\text { Innovation }\end{array}$ & $\begin{array}{l}\text { Both Product } \\
\text { and Process }\end{array}$ \\
\hline Small $\times$ Vertical & $0.969^{* * *}(8.65)$ & $0.474^{* * *}(4.34)$ & $0.120^{* * *}(4.19)$ & $-0.044^{*}(-1.71)$ & $0.225^{* * *}(6.56)$ \\
\hline Small $\times$ RO & $0.722^{* * *}(5.59)$ & $0.273^{* *}(2.17)$ & $0.107^{* * *}(3.28)$ & $-0.041(-1.36)$ & $0.143^{* * *}(4.10)$ \\
\hline Medium $\times$ Vertical & $0.641 * *(5.83)$ & $0.286^{* * *}(2.69)$ & $0.086^{* * *}(3.37)$ & $-0.023(-0.85)$ & $0.130^{* * *}(4.57)$ \\
\hline Medium $\times$ RO & $0.227^{*}(1.87)$ & $0.275^{* *}(2.37)$ & $0.010(0.49)$ & $0.044(1.29)$ & $0.059^{* *}(2.27)$ \\
\hline Large $\times$ Vertical & $0.448^{* * *}(5.26)$ & $0.425^{* * *}(5.05)$ & $0.031^{* *}(1.98)$ & $0.049^{* *}(2.07)$ & $0.109^{* * *}(5.48)$ \\
\hline Large $\times \mathrm{RO}$ & $0.018(0.22)$ & $0.208^{* *}(2.49)$ & $-0.014(-1.16)$ & $0.056^{\text {*** }}(2.28)$ & $0.020(1.34)$ \\
\hline Small & $-1.484^{* * *}(-17.97)$ & $-0.740^{* * *}(-10.69)$ & $-0.161^{* * *}(-13.06)$ & $-0.011(-0.63)$ & $-0.249^{* * *}(-19.47)$ \\
\hline Medium & $-1.183^{* * *}(-11.60)$ & $-0.552^{* * *}(-6.12)$ & $-0.107^{* * *}(-12.94)$ & $-0.049^{* *}(-2.20)$ & $-0.128^{* * *}(-16.89)$ \\
\hline Large & $-0.912^{* * *}(-8.01)$ & $-0.382^{* * *}(-3.66)$ & $-0.097^{* * *}(-7.72)$ & $-0.013(-0.48)$ & $-0.116^{* * *}(-9.89)$ \\
\hline Formal R\&D & $1.966^{* *}(2.05)$ & $1.190(1.22)$ & $0.215(1.35)$ & $0.087(0.33)$ & $0.336^{* *}(2.14)$ \\
\hline Design & $0.473^{* * *}(9.11)$ & $0.312^{* * *}(6.23)$ & $0.049^{* * *}(5.12)$ & $0.020(1.49)$ & $0.093^{* * *}(8.89)$ \\
\hline Consultant & $0.201^{* * *}(3.60)$ & $0.392^{* * *}(7.38)$ & $-0.004(-0.42)$ & $0.082^{* * *}(5.20)$ & $0.062^{* * *}(5.72)$ \\
\hline Age & $-0.001(-0.23)$ & $-0.001^{* *}(-2.17)$ & $0.001(0.84)$ & $-0.001^{* *}(-2.04)$ & $-0.001(-1.28)$ \\
\hline Foreign & $-0.001(-1.34)$ & $-0.001^{*}(-1.68)$ & $-0.000(-0.51)$ & $-0.001(-1.01)$ & $-0.001^{*}(-1.84)$ \\
\hline Export & $0.147(1.49)$ & $0.041(0.43)$ & $0.020(1.25)$ & $-0.006(-0.25)$ & $0.021(1.35)$ \\
\hline $\begin{array}{l}\text { Wald Test of Full } \\
\text { Model: } \chi^{2}\end{array}$ & \multicolumn{2}{|c|}{$2,159.35^{* * *}$} & & & \\
\hline Log Pseudo-Likelihood & \multirow{3}{*}{\multicolumn{2}{|c|}{ 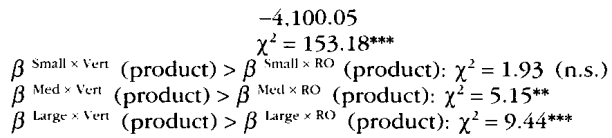 }} & & & \\
\hline $\mathrm{LR}-\chi^{2}: \rho=0$ & & & \multirow{2}{*}{\multicolumn{3}{|c|}{$\begin{array}{l}\beta^{\text {small } \times \text { Vert }} \text { (process) }>\beta^{\text {small } \times \text { RO }} \text { (process): } \chi^{2}=1.30 \text { (n.s.) } \\
\beta^{\text {Med } \times \text { Vert }}\left(\text { process) }>\beta^{\text {Med } \times \text { RO }} \text { (process): } \chi^{2}=0.01 \text { (n.s.) }\right. \\
\beta^{\text {Large } \times \operatorname{Ver}} \text { (process) }>\beta^{\text {Large } \times \text { Ro }} \text { (process): } \chi^{2}=2.48 \text { (n.s.) }\end{array}$}} \\
\hline Comparison Tests" & & & & & \\
\hline
\end{tabular}

t-Values are in parentheses. Sectoral and yearly dummies are included in the models. Marginal effects are computed at sample means. For dummy variables, the marginal effect corresponds to the discrete change from 0 to 1 . n.s., non-significant.

${ }^{a}$ Wald test comparing the difference of coefficients estimates (vertical versus RO) in each size category and type of innovation.

$* p<.10$.

${ }^{* *} p<.05$.

${ }^{* * *} p<.01$. 
medium-sized firms and product innovations.

Marginal effects from collaboration with both vertical and research organizations are larger for SMEs when firms achieve only product innovations or product and process innovations simultaneously. When firms achieve only process innovations, collaboration is only positive and significant for larger firms.

The results for the control variables hardly differ from those obtained in the previous models. The consistency and coherence of these results in all the estimations reveal the robustness of the models, especially for the effects related to technological collaboration. Lastly, the robustness of these results is strengthened by introducing 18 dummies to control for sector characteristics as well as yearly dummies (for reasons of clarity these coefficients are not included in the tables).

\section{Discussion and Conclusions}

The classic Schumpeterian debate over firm size and innovation undoubtedly reflects a complex relationship that may be influenced by several factors (Becheikh, Landry, and Amara 2006). There is, in fact, a large body of work that ascribes advantages and disadvantages to size and suggests that SMEs and large firms differ in their innovative behavior and outcomes (Rogers 2004; Cohen and Klepper 1996; Nooteboom 1994; among others). SMEs may enjoy some behavioral advantages, but certainly face weaknesses in regard to large firms' material advantages (Rothwell and Dodgson 1994). Hewitt-Dundas (2006) explicitly mentions the absence of external partners as one of the key factors to explain the poor innovative performance of small firms compared to large firms. With this in mind, our paper aims to contribute to the literature on the relationship of innovativeness and firm size and our understanding of SMEs' innovation processes. The paper specifically analyzes how collaboration acts as an input to the innovation process and how its impact differs depending on the innovation outcome pursued and the choice of collaboration partner.

Using a firm-level longitudinal survey for the period from 1998 to 2002, this study finds that technological collaboration contributes to improving the innovativeness of SMEs. In addition, for small firms the marginal effect of technological collaboration is significantly higher than for large firms. These findings are in line with those obtained by Feldman (1994) for the United States and Audretsch and Vivarelli (1996) for Italy. Both these studies show how external technological infrastructure appears to benefit the innovative activity of small firms more than that of larger firms-their explanation being that such external infrastructure is not as decisive for large firms with more capabilities and internal resources. In the same way, our research confirms that collaboration is a critical input for the innovation processes of SMEs, one that enables them to get closer to the levels of innovativeness of their larger counterparts (as suggested in Figure 1). Thus, collaboration is a factor that permits a narrowing of the innovation gap between small and large firms.

This result is most clear for product innovations. Research by Cohen and Klepper (1996) and Fritsch and Meschede (2001) provide one possible explanation for the different impact of collaboration on product and process innovations. These papers show that SMEs allocate more resources to product than process innovations. As process innovations are less saleable than product innovations, large firms receive scale benefits because of the indivisibility of the innovation activities: a larger volume of sales means that the fixed costs of innovation can be spread over a larger sales base. Appropriability 
conditions also differ for both kinds of innovation; licensing methods are not available or are less effective for process innovations (Rogers 2004). Although collaboration helps to bring SMEs' levels of innovativeness closer to those of large firms, then, it is not surprising that the difference continues to be larger for process innovations, which are inherently less attractive for SMEs (Hoffman et al. 1998).

The empirical analysis also makes it possible to see the impact of different types of partners. In line with the work by Miotti and Sachwald (2003), vertical collaboration contributes more than collaboration with research organizations to the achievement of product innovations. This effect is particularly significant for medium and large firms. In contrast, notable differences between both types of collaboration hardly exist for the smallest firms. These results may appear to run counter to our expectation of a greater impact for vertical collaboration. Although research organizations have traditionally been viewed as institutions focused on basic research activities, in recent years these institutions have evolved (partly as a result of government pressure) and now perform more and more applied research that contributes to improving firm competitiveness (Surroca and Santamaría 2007). This fact could be behind the significant impact of collaboration with research organizations on firm innovativeness, which is comparable to that of vertical collaboration.

Our study contributes empirical evidence similar to Mytelka's (1991) finding that a firm's competitiveness may in fact be determined more by its external network than its size. Indeed, our main finding shows how technological collaboration can boost SMEs' capabilities and innovativeness, tempering the material disadvantages linked to smaller size that a priori exist in comparison with larger firms. SMEs, however, are less likely to collaborate than large firms (particularly when the firm is smaller). Possible explanations for this may lie in the greater difficulty that SMEs seem to have reaching technological agreements. In particular, SMEs may be at a disadvantage with their counterparts when it comes to setting up lines of communication with external sources of scientific and technological experience (Rothwell 1991). In addition, SMEs that collaborate with large firms are faced with problems of asymmetry and unequal power balance (Blomqvist, Hurmelinna, and Seppänen 2005). Indeed, evidence exists that SMEs prefer outsourcing to alliance building, largely because of the high risks and costs of managing an alliance, along with an understandable wariness about choosing a partner when there may be few opportunities to rectify a bad choice (Narula 2004).

Technological collaboration does, in fact, have a downside. The disadvantages of joint $\mathrm{R} \& \mathrm{D}$ are caused by transaction costs (Pisano 1990; Williamson 1989), especially for coordinating, managing, and controlling the activities of the different parties involved. This makes firms-particularly small ones-view inter-firm alliances as risky and stops them from collaborating as intensely as their large counterparts. In addition, as becoming a partner in an alliance is often contingent on what the firm can contribute to the partnership, a major challenge for the small firm is how to make itself attractive as a potential partner (Barnir and Smith 2002 , p. 221).

Given the benefits that collaboration brings in bridging the gap between SMEs and large firms, future research should try to deepen the understanding of the problems and reluctance of SMEs to become involved in technological collaborations. Once this has been resolved, the effectiveness of the varying mechanisms and policies to strengthen technological collaboration and boost the competitiveness and innovativeness of 
SMEs should be analyzed from an institutional and managerial point of view.

This work is not free from limitations. It would be desirable to have more complete information on the improvement in innovativeness - for example, via quantitative measures of innovation performance. Future studies may extend the instrumentalization of this concept, using other methodologies and sources of information. Other interesting opportunities for research in this area lie in performing more specific sector analyses. Although this study has controlled for sector characteristics, a more detailed analysis of more or less technologyintensive sectors will certainly shed new light on the impact of technological collaboration on SME innovativeness. Lastly, we would like to reiterate the importance of SMEs in industry and point out the generalizability of these findings. Although our data are limited to Spain, the SME patterns of collaboration seen in this study are common to the majority of European countries.

\section{References}

Acs, Z., D. Audretsch, and M. Feldman (1994). "R\&D Spillovers and Recipient Firm Size," Review of Economics and Statistics 76(2), 336-340.

Ahern, R. (1993). "Implications of Strategic Alliances for Small R\&D-Intensive Firms," Environment and Planning $A$ 25, 1511-1526.

Audretsch, D. B., and M. Vivarelli (1996). "Firms Size and R\&D Spillovers: Evidence from Italy," Small Business Economics 8, 249-258.

Barnir, A., and K. A. Smith (2002). "Interfirm Alliances in the Small Business: The Role of Social Networks," Journal of Small Business Management 4(3), 219-232.

Baum, J. A. C., T. Calabrese, and B. S. Silverman (2000). "Don't Go It Alone: Alliance Network Composition and Startups Performance in Canadian
Biotechnology," Strategic Management Journal 21, 267-294.

Bayona, C., 'T. Garcia-Marco, and E. Huerta (2002). "Collaboration in R\&D with Universities and Research Centres: An Empirical Study of Spanish Firms," RED Management 32 , 321-341.

Becheikh, N., R. Landry, and N. Amara (2006). "Lessons from Innovation Empirical Studies in the Manufacturing Sector: A Systematic Review of the Literature from 1993-2003," Technovation 26, 644-664.

Beise, M., and H. Stahl (1999). "Public Research and Industrial Innovations in Germany," Research Policy 28, 397422.

Beneito, P. (2006). "The Innovative Performance of In-House and Contracted R\&D in Terms of Patents and Utility Models," Research Policy 35, 502-517.

Bierly, P. E., and P. S. Daly (2007). "Sources of External Organisational Learning in Small Manufacturing Firms," International Journal of Technology Management 38, 45-68.

Blomqvist, K., P. Hurmelinna, and R. Seppänen (2005). "Playing the Collaboration Game Right-Balancing Trust and Contracting," Technovation $25,497-504$.

Bougrain, F., and B. Haudeville (2002). "Innovation, Collaboration and SMEs Internal Research Capacities," Research Policy 31, 735-747.

Bozeman, B. (2000). "Technology Transfer and Public Policy: A Review of Research and Theory," Research Policy 29, 627-655.

Cassiman, B., and R. Veugelers (2002). "R\&D Co-Operation and Spillovers: Some Empirical Evidence from Belgium," American Economic Review 92, 1169-1185.

Cohen, W. M. (1995). "Empirical Studies of Innovative Activity," in Handbook of the Economics of Innovation and Technological Change. Ed P. Stoneman. Oxford: Blackwell, 182-264. 
Cohen, W. M., and S. Klepper (1992). "The Anatomy of Industry R\&D Intensity Distributions," American Economic Review 82, 773-799.

(1996). "Firm Size and the Nature of Innovation Within Industries: The Case of Process and Product R\&D," Review of Economics and Statistics 78(2), 232-243.

Cuervo-Cazurra, A., and C. A. Un (2007). "Regional Economic Integration and R\&D Investment," Research Policy 36, 227-246.

Dickson, P. H., K. M. Weaver, and F. Hoy (2006). "Opportunism in the R\&D Alliances of SMEs: The Roles of the Institutional Environment and SME Size," Journal of Business Venturing 21, 487-513.

Drejer, I., and B. H. Jørgensen (2006). "The Dynamic Creation of Knowledge: Analysing Public-Private Collaborations," Technovation 25, 83-94.

Duysters, G., G. Kok, and M. Vaandrager (1999). "Crafting Successful Strategic Technology Partnerships," RED Management 29(4), 343-351.

Edwards, T., R. Delbridge, and $M$. Munday (2005). "Understanding Innovation in Small and Medium-Sized Enterprises: A Process Manifest," Technovation 25, 1119-1127.

European Commission (2004). Innovation in Europe. Results for the $E U$, Iceland and Norway. Data 19982001. Luxembourg: Eurostat, European Commission.

Feldman, M. P. (1994). "Knowledge Complementary and Innovation," Small Business Economics 6, 363372.

Forrest, J. E. (1990). "Strategic Alliances and the Small Technology-Based Firm," Journal of Small Business Management 28(3), 37-45.

Freel, M. (2003). "Sectoral Patterns of Small Firm Innovation, Networking and Proximity," Research Policy 32, 751-770.
Freel, M. S. (2005). "Patterns of Innovation and Skills in Small Firms," Technovation $25,123-134$.

Fritsch, M., and M. Meschede (2001) "Product Innovation, Process Innovation, and Size," Review of Industrial Organization 19, 335-350.

Galende, J., and J. M. de la Fuente (2003). "Internal Factors Determining a Firm's Innovative Behaviour," Research Policy 32, 715-736.

Geisler, E. (1997). "Intersector Technology Cooperation: Hard Myths, Soft Facts," Technovation 17(6), 309320.

Gibbons, M., C. Limoges, H. Nowotny, S. Schwartzman, P. Scott, and M. Trow (1994). The New Production of Knowledge: The Dynamics of Science and Research in Contemporary Societies. London: Sage Publications.

Greene, W. (2000). Econometric Analy sis, 4th ed. Upper Saddle River, NJ: Prentice Hall.

Hagedoorn, J. (1993). "Understanding the Rationale of Strategic Technology Partnering: Interorganisational Modes of Co-Operation and Sectoral Differences," Strategic Management Journal 14, 371-385.

- (1996). "Trends and Patterns in Strategic Technology Partnering Since the Early Seventies," Strategic Management Journal 14, 371385.

(2002). "Inter-Firm R\&D Partnerships-An Overview of Pattern and Trends since 1960," Research Policy 31, 477-492.

Heckman, J. (1981). "Statistical Models for Discrete Panel Data," in The Econometrics of Panel Data. Eds. D. McFadden and C. Manski. Cambridge MA: MIT Press, 114-178.

Hewitt-Dundas, N. (2006), "Resource and Capability Constraints to Innovation in Small and Large Plants," Small Business Economics 26, 257-277.

Hoffman, K., M. Parejo, J. Bessant, and L. Perren (1998). "Small Firms, R\&D 
Technology and Innovation in the UK: A Literature Review," Technovation 18(1), 39-55.

Hsiao, C. (1986). Analysis of Panel Data. New York: Cambridge university Press.

Huergo, E. (2006). "The Role of Technological Management as a Source of Innovation: Evidence from Spanish Manufacturing Firms," Research Policy 35, 1377-1388.

Izushi, H. (2003). "Impact of the Length of Relationships Upon the Use of Research Institutes by SMEs," Research Policy 32, 771-788.

Jones, O., and F. Tilley (2003). Competitive Advantage in SMEs: Organizing for Innovation and Change. Chichester: Wiley.

Kumar, N., and M. Saqib (1996). "Firm Size, Opportunities for Adaptation and In-House R\&D Activity in Developing Countries: The Case of Indian Manufacturing," Research Policy 25(5), 713-722.

Lambrecht, J., and F. Pirnay (2005). "An Evaluation of Public Support Measures for Private External Consultancies to SMEs in the Walloon Region of Belgium," Entrepreneurship and Regional Development 17, 89-108.

Lewin, A. Y., and S. Massini (2003). "Knowledge Creation and Organizational Capabilities of Innovating and Imitating Firms," in Organizations as Knowledge Systems. Eds. H. Tsoukas and N. Mylonopoulos. New York: Palgrave, 209-237.

Martínez-Ros, E. (2000). "Explaining the Decisions to Carry Out Product and Process Innovations: The Spanish Case," Journal of High Technology Management Research 10, 223242.

Miles, G., S. B. Preece, and M. C. Baetz (1999). "Dangers of Dependence: The Impact of Strategic Alliance Use by Small Technology-Based Firms," Journal of Small Business Management 37(2), 20-29.
Miotti, L., and F. Sachwald (2003). "CoOperative R\&D: Why and with Whom? An Integrated Framework of Analysis," Research Policy 32, 14811499.

Mytelka, L. (1991). "Crisis, Technological Change and the Strategic Alliance," in Strategic Partnerships and the World Economy. Ed. L. Mytelka. London: Pinter, 7-34.

Narula, R. (2004). "R\&D Collaboration by SMEs: New Opportunities and Limitations in the Face of Globalization," Technovation 24, 153-161.

Neter, J., W. Wasserman, and M. H. Kutner (1989). Applied Regression Models. Homewood, IL: Irwin.

Nieto, M. J., and L. Santamaria (2007). "The Importance of Diverse Collaborative Networks for the Novelty of Product Innovation," Technovation 27, 367-377.

Nooteboom, B. (1994). "Innovation and Diffusion in Small Firms: Theory and Evidence," Small Business Economics 6, 327-347.

Okamuro, H. (2007). "Determinants of Successful R\&D Cooperation in Japanese Small Businesses: The Impact of Organizational and Contractual Characteristics," Research Policy 36, 15291544.

Ornaghi, C. (2006). "Spillovers in Product and Process Innovation: Evidence from Manufacturing Firms," International Journal of Industrial Organization 24, 349-380.

Piergiovanni, R., E. Santarelli, and M. Vivarelli (1997). "From which Source Do Small Firms Derive Their Innovative Inputs? Some Evidence from Italian Industry," Review of Industrial Organisation 12, 243-258.

Piga, C. A., and M. Vivarelli (2004). "Internal and External R\&D: A Sample Selection Approach," Oxford Bulletin of Economics and Statistics 66(4), 457-482.

Pisano, G. P. (1990). "The R\&D Boundaries of the Firm: An Empirical 
Analysis," Administrative Science Quarterly 35, 153-176.

Powell, W., K. Koput, and L. Smith-Doerr (1996). "Interorganizational Collaboration and the Locus of Innovation: Networks of Learning in Biotechnology," Administrative Science Quarterly 41(1), 116-145.

Rogers, M. (2004). "Networks, Firm Size and Innovation," Small Business Economics 22, 141-153.

Rolfo, S., and G. Calabrese (2003). "Traditional SMEs and Innovation: The Role of the Industrial Policy in Italy," Entrepreneurship and Regional Development 15(3), 253-271.

Rothwell, R. (1991). "External Networking and Innovation in Small and Medium-Sized Manufacturing in Europe," Technovation 11(2), 93112.

Rothwell, R., and M. Dodgson (1994). "Innovation and Size of Firm," in The Handbook of Industrial Innovation. Eds. M. Dodgson and R. Rothwell. Aldershot Hants: Edward Elgar.

Schumpeter, J. A. (1942). Capitalism, Socialism and Democracy. New York: Harper and Row.

Smallbone, D., D. North, and R. Leigh (1993). "The Use of External Assistance by Mature SMEs in the UK: Some Policy Implications," Entrepreneurship and Regional Development 5, 279-295.

Smith, R. J., and R. W. Blundell (1986). "An Exogeneity Test for a Simultaneous Equation Tobit Model with an Application to Labor Supply," Econometrica 54(4), 679-686.

Stock, G. N., N. P. Greis, and W. A. Fischer (2002). "Firm Size and Dynamic Technological Innovation," Technovation 22, 537-549.

Surroca, J., and L. Santamaría (2007). "La Cooperación Tecnológica Como Determinante de Los Resultados Empresariales," Cuadernos de Economía $y$ Dirección de la Empresa 33, 3162.
Tether, B. (2002). "Who Co-Operates for Innovation, and Why. An Empirical Analysis," Research Policy 31, 947967.

Tsai, K.-H., and J.-C. Wang (2005). "Does R\&D Performance Decline with Firm Size? A Re-Examination in Terms of Elasticity," Research Policy 34, 966976.

Van Dijk, B., R. Den Hertog, B. Menkveld, and R. Thurik (1997). "Some New Evidence on the Determinants of Large- and Small-Firm Innovation," Small Business Economics 9, 335-343.

Verhees, F. J. H. M., and M. T. G. Meulenberg (2004). "Market Orientation, Innovativeness, Product Innovation, and Performance in Small Firms," Journal of Small Business Management 42(2), 86-91.

Veugelers, R., and B. Cassiman (1999). "Make and Buy in Innovation Strategies: Evidence from Belgian Manufacturing Firms," Research Policy 28, 63-80.

Von Hippel, E. (1988). Sources of Innovation. Oxford: Oxford University Press.

Vossen, R. W. (1998). "Relative Strengths and Weaknesses of Small Firms in Innovation," International Small Business Journal 16(3), 88-93.

Vuola, O., and A. P. Hameri (2006). "Mutually Benefiting Joint Innovation Process Between Industry and BigScience," Technovation 26, 3-12.

Walsh, V. (1996). "Design, Innovation and the Boundaries of the Firm," Research Policy 25, 509-529.

Whitley, R. (2002). "Developing Innovative Competences: The Role of Institutional Frameworks," Industrial and Corporate Change 11, 497-528.

Williamson, O. E. (1989). "Transaction Cost Economics," in Handbook of Industrial Organization. Eds. R. Schmalensee and R. D. Willig. Amsterdam: North-Holland, 135-182.

Wolff, J. A., and T. L. Pett (2006). "SmallFirm Performance: Modelling the Role 
of Product and Process Improvements," Journal of Small Business Management 44(2), 268-284.

Zahra, S. A., R. D. Ireland, and M. A. Hitt (2000). "International Expansion by
New Venture Firms: International Diversity, Mode of Market Entry, Technological Learning, and Performance," Academy of Management Journal 43(5), 925-950. 


\section{Appendix}

Table A1

Product and Process Innovations, Technological Collaboration, and Firm Size (Sub Sample of Innovators)

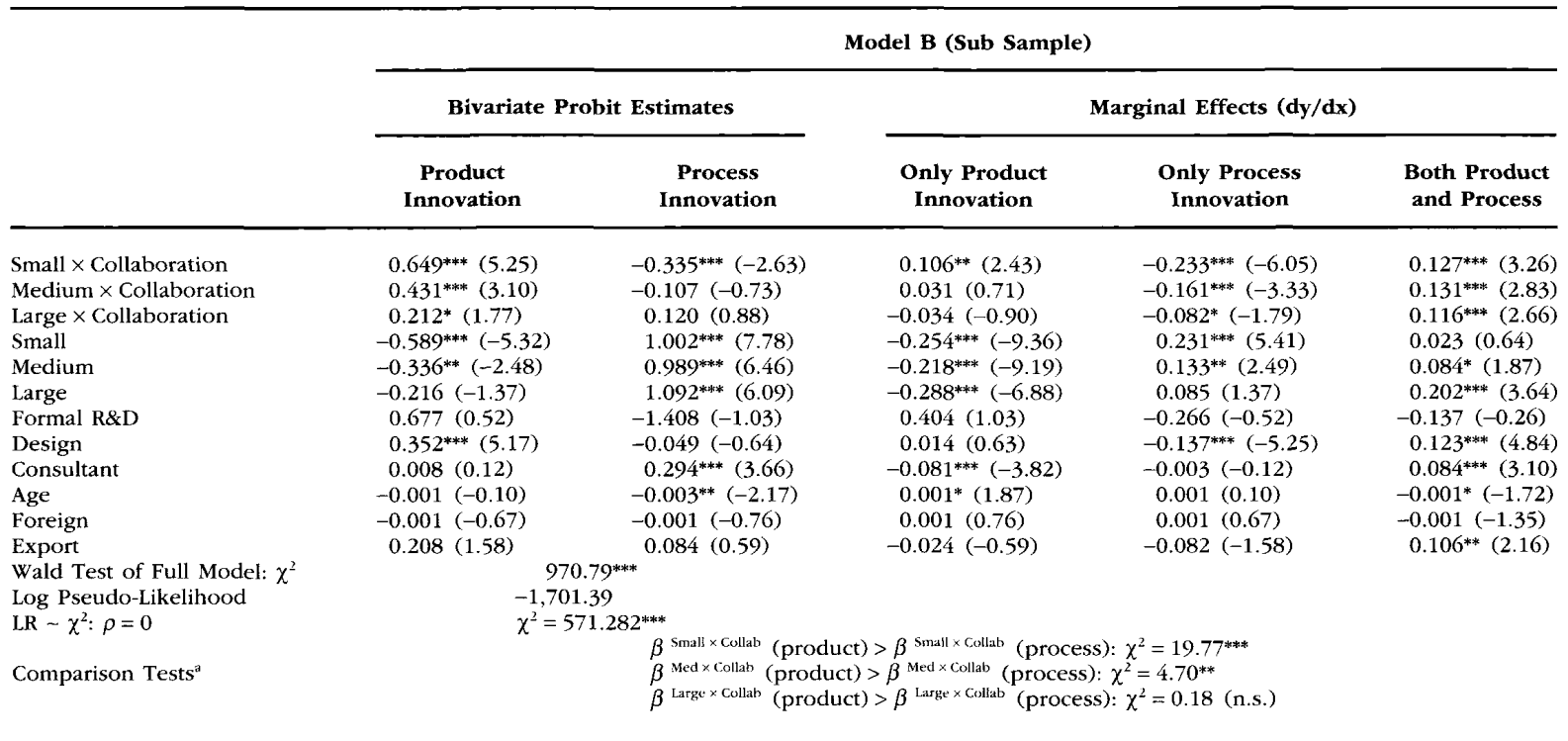

t-Values are in parentheses. Sectoral and yearly dummies are included in the models. Marginal effects are computed at sample means. For dummy variables, the marginal effect corresponds to the discrete change from 0 to 1 . n.s., non-significant.

${ }^{\mathrm{a}}$ Wald test comparing the difference of coefficients estimates (product innovation versus process innovation) in each size category.

${ }^{*} p<.10$.

$* * p<.05$.

${ }^{* * * *} p<.01$. 
Table A2

Type of Partner, Technological Collaboration, and Firm Size (Sub Sample of Innovators)

Model C (Sub Sample)

\begin{tabular}{|c|c|c|c|c|c|}
\hline & \multicolumn{2}{|c|}{ Bivariate Probit Estimates } & \multicolumn{3}{|c|}{ Marginal Effects (dy/dx) } \\
\hline & $\begin{array}{c}\text { Product } \\
\text { Innovation }\end{array}$ & $\begin{array}{c}\text { Process } \\
\text { Innovation }\end{array}$ & $\begin{array}{l}\text { Only Product } \\
\text { Innovation }\end{array}$ & $\begin{array}{l}\text { Only Process } \\
\text { Innovation }\end{array}$ & $\begin{array}{l}\text { Both Product } \\
\text { and Process }\end{array}$ \\
\hline Small $\times$ Vertical & $0.734^{* * * *}(5.04)$ & $-0.192(-1.36)$ & $0.058(1.25)$ & $-0.256^{* * * *}(-6.13)$ & $0.197^{* * *}(4.42)$ \\
\hline Small $\times$ RO & $0.482^{* * *}(2.97)$ & $-0.382^{* *}(-2.39)$ & $0.123^{* *}(2.17)$ & $-0.177^{* * * *}(-3.29)$ & $0.054(1.13)$ \\
\hline Medium $\times$ Vertical & $0.405^{* * * *}(4.02)$ & $-0.337^{* *}(-2.29)$ & $0.106^{* *}(2.06)$ & $-0.152^{* * *}(-3.01)$ & $0.045(0.93)$ \\
\hline Medium $\times$ RO & $0.224(1.37)$ & $0.413^{* *}(2.37)$ & $-0.099^{* * *}(-2.89)$ & $-0.086(-1.41)$ & $0.186^{* * *}(3.25)$ \\
\hline Large $\times$ Vertical & $0.276^{* *}(2.52)$ & $0.148(1.21)$ & $-0.041(-1.25)$ & $-0.107^{* * *}(-2.59)$ & $0.148^{* * *}(3.53)$ \\
\hline Large $\times$ RO & $-0.145(-1.35)$ & $0.248^{\text {** }}(2.10)$ & $-0.067^{* *}(-2.23)$ & $0.057(1.35)$ & $0.009(0.24)$ \\
\hline Small & $-0.601^{* * *}(-5.46)$ & $-0.998^{* * * *}(-7.78)$ & $-0.251^{* * *}(-9.35)$ & $0.235^{* * * *}(5.57)$ & $0.016(0.47)$ \\
\hline Medium & $-0.327^{* *}(-2.45)$ & $0.982^{* * *}(6.49)$ & $-0.215^{* * *}(-9.22)$ & $0.129^{* *}(2.45)$ & $0.085^{*}(1.89)$ \\
\hline Large & $-0.128(-0.85)$ & $0.974^{* * *}(5.72)$ & $-0.257^{* * *}(-6.38)$ & $0.050(0.85)$ & $0.207^{\text {k*k }}(3.94)$ \\
\hline Formal R\&D & $0.501(0.38)$ & $-2.141(-1.55)$ & $0.609(1.55)$ & $-0.197(-0.38)$ & $-0.412(-0.78)$ \\
\hline Design & $0.331^{* * *}(4.83)$ & $-0.054(-0.73)$ & $0.015(0.72)$ & $-0.129^{* * * *}(-4.90)$ & $0.113^{*+* *}(4.44)$ \\
\hline Consultant & $0.009(0.13)$ & $0.271^{* * *}(3.34)$ & $-0.074^{* * *}(-3.42)$ & $-0.003(-0.13)$ & $0.078^{* * *}(2.84)$ \\
\hline Age & $0.001(0.16)$ & $-0.003^{*}(-1.92)$ & $0.001 *(1.92)$ & $-0.001(-0.16)$ & $-0.001(-1.49)$ \\
\hline Foreign & $-0.001 \quad(-0.83)$ & $-0.001(-0.67)$ & $0.001(0.67)$ & $0.001(0.83)$ & $-0.001(-1.45)$ \\
\hline Export & $0.210(1.59)$ & $0.067(0.47)$ & $-0.019(-0.47)$ & $-0.083(-1.59)$ & $0.102^{* *}(2.09)$ \\
\hline $\begin{array}{l}\text { Wald Test of } \\
\text { Full Model: } \chi^{2}\end{array}$ & \multicolumn{2}{|c|}{$974.14^{* * * *}$} & & & \\
\hline Log Pseudo-Likelihood & \multicolumn{2}{|c|}{$-1,682.36$} & & & \\
\hline $\mathrm{LR} \sim \chi^{2}: \rho=0$ & \multirow{2}{*}{\multicolumn{2}{|c|}{ 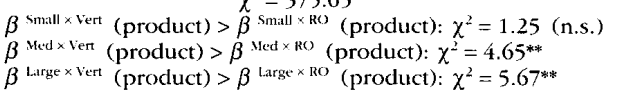 }} & \multirow{2}{*}{\multicolumn{3}{|c|}{ 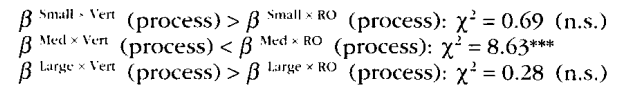 }} \\
\hline Comparison Testsi & & & & & \\
\hline
\end{tabular}

t-Values are in parentheses. Sectoral and yearly dummies are included in the models. Marginal effects are computed at sample means. For dummy variables, the marginal effect corresponds to the discrete change from 0 to 1 . n.s., non-significant.

"Wald test comparing the difference of coefficients estimates (vertical versus RO) in each size category and type of innovation.

${ }^{*} p<.10$.

${ }^{* * *} p<.05$.

$* * * * 0.01$. 